$11-2013$

\title{
Sternal wound infection caused by Mycobacterium chelonae.
}

\author{
Shinya Unai \\ Thomas Jefferson University \\ Joseph Miessau \\ Thomas Jefferson University \\ Pawel Karbowski \\ Thomas Jefferson University \\ Gurjyot Bajwa \\ Thomas Jefferson University \\ Hitoshi Hirose \\ Thomas Jefferson University \\ Follow this and additional works at: https://jdc.jefferson.edu/surgeryfp \\ Part of the Surgery Commons \\ Let us know how access to this document benefits you
}

\section{Recommended Citation}

Unai, Shinya; Miessau, Joseph; Karbowski, Pawel; Bajwa, Gurjyot; and Hirose, Hitoshi, "Sternal wound infection caused by Mycobacterium chelonae." (2013). Department of Surgery Faculty Papers. Paper 129.

https://jdc.jefferson.edu/surgeryfp/129

This Article is brought to you for free and open access by the Jefferson Digital Commons. The Jefferson Digital Commons is a service of Thomas Jefferson University's Center for Teaching and Learning (CTL). The Commons is a showcase for Jefferson books and journals, peer-reviewed scholarly publications, unique historical collections from the University archives, and teaching tools. The Jefferson Digital Commons allows researchers and interested readers anywhere in the world to learn about and keep up to date with Jefferson scholarship. This article has been accepted for inclusion in Department of Surgery Faculty Papers by an authorized administrator of the Jefferson Digital Commons. For more information, please contact: JeffersonDigitalCommons@jefferson.edu. 
Sternal wound infection caused by Mycobacterium chelonae. A case report and review of literature.

Shinya Unai, MD ${ }^{1}$, Joseph Miessau, MS ${ }^{1}$, Pawel Karbowski, $\mathrm{MS}^{1}$, Gurjyot Bajwa, MD ${ }^{1}$, Hitoshi Hirose, $\mathrm{MD}^{1}$.

1. From Division of Cardiothoracic Surgery, Department of Surgery, Thomas Jefferson University, Philadelphia, PA.

Short running Title: Mediastinitis caused by Mycobacterium chelonae

Corresponding author: Hitoshi Hirose, MD.

Division of Cardiothoracic Surgery, Department of Surgery, Thomas Jefferson University 1025 Walnut Street Room 605, Philadelphia, PA 19107, USA.

Tel: $\quad 215-955-5654 \quad$ Fax: $215-955-6010$

E-mail: genex@nifty.com

Total word count 5396 


\begin{abstract}
Introduction: Sternal wound infection caused by Mycobacterium chelonae, a member of rapidly growing non-tuberculous mycobacteria, is rare and may present without signs and symptoms of systemic infection.
\end{abstract}

Methods: We present a patient who had a Mycobacterium chelonae infection of the sternum following excision of a left atrial myxoma and conducted a review of the literature from 1976 to 2013.

Results:70 cases of NTM sternal wound infection after cardiac surgery was identified, including 6 outbreaks and 10 sporadic cases including the present case. 34 cases were isolated coronary artery bypass grafting surgery (CABG), 16 cases were isolated valve replacement and 2 cases were valve replacement with CABG. The age range of the patients was between 6 and 78 years. The average time from the surgery was $49 \pm 58$ days which was longer than usual bacterial mediastinitis. The overall mortality rate was $29 \%$.

Conclusion: NTM sternal wound infection is rare but may be fatal if not properly treated. The toxic signs are often subtle and it will take longer to isolate compared to typical bacterial mediastinitis. Early recognition, the use of appropriate antibiotics based on susceptibility tests and aggressive surgical debridement is required for full recovery. (Word count of abstract: 197)

Key words: cardiac surgery, mediastinitis, mycobacterium, surgical site infection, acid fast bacilli 


\section{Introduction}

Sternal wound infection has remained one of the most devastating complications of cardiac surgery with its incidence of $1-3 \% .^{1}$ The most common organisms are Staphylococci group and gram-negative bacilli. ${ }^{1} \quad$ Therefore, standard prophylactic antibiotics are cephalosporins. ${ }^{2,3}$ However, most non-tuberculous mycobacteria (NTM) are not sensitive to cephalosporins. ${ }^{4}$ We report a case of Mycobacterium chelonae infection of the sternum following excision of a left atrial myxoma in a 60-year-old man. This case report illustrates the unique clinical presentation and the treatment for NTM sternal wound infection and would alert clinicians that NTM may be a cause of culture negative sternal wound infection.

\section{Case Report}

A 60-year-old male with a past medical history of hypertension, hyperlipidemia and multiple episodes of right lower lobe pneumonia secondary to chronic aspiration was found to have a left atrial myxoma $(4 \times 2.5 \mathrm{~cm})$. He underwent excision of the myxoma, which was complicated by postoperative bleeding and tamponade requiring re-exploration on postoperative day 0. Otherwise, he had an uneventful hospital course and he was discharged to a rehabilitation facility on postoperative day 7. Three months later, on a scheduled office visit, there was serosanguinous drainage from the sternal incision. He denied pain, fever, chill, malaise or fatigue. He was admitted to the hospital with a diagnosis of sternal wound infection. He was afebrile. Physical examination showed mild serosanguinous drainage from the mid-sternal incision without erythema or tenderness. Laboratory data showed white blood cell count (WBC) 7.6 B/L and procalcitonin $0.11 \mathrm{ng} / \mathrm{ml}$. Chest CT (Figure 1) showed a sub-sternal fluid collection with sternal dehiscence. He was scheduled for a wound exploration and drainage in the operating room. Antibiotics were not started until the operative exploration due 
to his stable condition. His sternal incision was opened, all the wires were removed, and the wound was closed with a vacuum assisted closing device. The gram stain and acid-fast stain of the drainage and tissue obtained in the operating room showed no organisms. The culture initially showed very light growth of coagulase negative staphylococcus and propionibacterium acnes; thus, vancomycin was started. However, 5 days later, the culture turned positive for acid-fast organism. Antibiotic regimens were modified to tobramycin, imipenem, moxifloxacin and clarithromycin, in addition to vancomycin. He underwent a total sternectomy on postoperative day 6 and his chest was closed on postoperative day 12 with a pectoralis major muscle flaps. The specimen was sent to FOCUS Diagnostics (Cypress, CA) for further speciation and susceptibility testing, and the organism was later identified as Mycobacterium chelonae. The antibiotics were changed to tigecycline and clarithromycin based on the sensitivity. Tigecycline was continued for 2 weeks. He was discharged on postoperative day 32 on oral clarithromycin, which was continued for 6 months. He is currently being followed as an outpatient without relapse for 1 year.

\section{Discussion}

Bacteriology: Mycobacterium chelonae is one of the species of rapidly growing NTM (RGM). The most common strains among RGM are Mycobacterium fortuitum, Mycobacterium abscessus and Mycobacterium chelonae. ${ }^{5} \quad$ NTM is ubiquitous in the environment and has been isolated from house dust, raw and pasteurized milk, fish, cattle, soil and various water related sources, including water in hospital tanks as well as scrub sinks in operating room., 6,7 They have been isolated from sputum and saliva of healthy adult humans. ${ }^{7}$ Some NTM strains are resistant to the commonly used disinfectants such as organomercurials, chlorine, formaldehyde, and alkaline glutaraldehyde. ${ }^{8}$

Lung infection, post-traumatic wound infection, post surgical wound infection, and 
catheter related infection are the common clinical manifestations caused by NTM. ${ }^{9}$ NTM was also reported to be the pathogen of meningitis, peritonitis, salpingitis, prostatitis and epididymitis. $^{7}$ In cardiac surgery, 25 Hancock porcine valves implanted at ten medical centers were contaminated by M. chelonei subspecies chelonei in 1976-77.10,11 These valves were found to be contaminated during the harvesting process from pigs, ${ }^{12}$ and the organism was relatively resistance to $2 \%$ formaldehyde which was used for valve sterilization. ${ }^{10,13,14}$ Two of the 24 patients ( 1 patient received 2 valves) developed mycobacterium infection; mycobacterial pericarditis and aortic root abscess. ${ }^{10}$ Few cases of isolated native valve endocarditis caused by M. abscessus are reported as well. ${ }^{15-17}$

To the best of our knowledge, a total of 70 cases of NTM sternal wound infection after cardiac surgery were reported, including 6 outbreaks in the 1970s -1980 s and 10 sporadic cases including the present case (Table 1). Interestingly, all of the NTMs that were isolated from sternal wound infections were RGM. M. fortuitum was isolated in most cases, followed by $M$. abscessus, and M. peregrinum. An isolated case of M.porcinum sternal wound infection was reported from Spain, and M. smegmatis was submitted to Tyler Mycobacteria / Nocardia laboratory from sternal wound infection that occurred in Texas and California. ${ }^{18}$

In 1966, M. fortuitum was divided into three subgroups; biotypes A, B and C, based on the differences in acid production from carbohydrates. ${ }^{9,} 19 \quad$ In 1974 , Pattyn renamed them as $M$. fortuitum biovariant fortuitum, M. fortuitum biovariant peregrinum, and an unnamed third

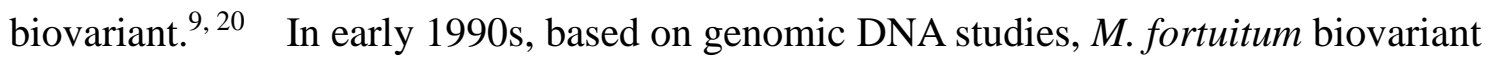
fortuitum and M. fortuitum biovariant peregrinum were upgraded to species status, $M$. fortuitum and $M$. peregrinum respectively. ${ }^{9,21,22}$ Therefore, "M. fortuitum" infections reported before 1990s may have not accurately separated the subgroups of M. fortuitum. For example, the organism isolated in the second outbreak in Colorado was initially reported as " $M$. fortuitum" but 
was later identified as $M$. fortuitum biovariant fortuitum. ${ }^{23}$

Another RGM, M. chelonei was isolated from the lungs of turtles in 1903 by

Friedmann ${ }^{24}$, and the name was changed to the more correct Latin; M. chelonae in $1984 .^{25} M$. abscessus was identified by Moore and Frerichs in 1953 from a knee abscess. In the past, $M$. abscesses and M. chelonei were believed to be the same organism because they had almost identical biochemical features. In 1972, Kubica demonstrated that $M$. chelonei and $M$. abscesses were different and needed to be classified as subspecies. These were renamed as $M$. chelonae subspecies chelonae and M. chelonae subspecies abscessus. ${ }^{26}$ Genomic DNA studies showed that the two subspecies were different species, and once again, they were renamed as $M$. chelonae and M. abscessus in early 1990s. ${ }^{21,22}$ Like in the case of M. fortuitum, little effort was made to differentiate the two species in the reports before $1990 .{ }^{9}$ The organism that was isolated in the first outbreak in North Carolina was initially reported to be "M. chelonei" but was later identified as M. chelonae subspecies abscessus. ${ }^{27} \quad$ To the best of our knowledge, other than our report, sternal wound infections caused by $M$. chelonae (chelonei) have been only reported once, by Yew in $1988^{28}$, when M. chelonei and M. abscessus might have not been differentiated. In most of the reported outbreaks of RGM sternal infection, the source-identification failed despite extensive workup. In 1976, Robicsek reported an outbreak of RGM sternal infections that occurred in 19 of 80 patients who underwent cardiac surgery. ${ }^{29}$ He cultured materials used in the operating room such as bone wax, gauze, povidone-iodine, needle and wire, surgeon's hair, nose, throat and hands, but was unsuccessful. In another outbreak, Kuritsky reported that the water for cooling the cardioplegia solution in the operating room was considered to be a source of contamination by $M$. chelonae. ${ }^{30}$ From an epidemiological point of view, the fact that the reported outbreaks were caused by different strains, some outbreaks had more than one strain, the outbreaks occurred in areas of high endemicity of all forms of NTM infection, 
suggests that the outbreaks of NTM infection could be more related to the local environmental source, rather than a contaminated surgical material. ${ }^{31}$

\section{Characteristics of NTM Sternal infection: $\quad$ Among the 70 cases of NTM sternal} infections, 34 cases were isolated coronary artery bypass grafting surgery (CABG), 16 cases were isolated valve replacement and 2 cases were valve replacement with CABG. The age range of the patients was between 6 and 78 years. The patients were not necessarily immune-compromised; however, prolonged surgical exposure, the use of cardiopulmonary bypass, prosthetic material, intravenous and intra-arterial catheters for monitoring and infusion may increase the risk of nosocomial infections. ${ }^{32}$ Almost all patients had an uneventful postoperative course and most of the patients were initially discharged from hospital in a reasonable time period with stable condition.

Sternal wound infections caused by RGM have unique manifestations compared to typical bacterial infections. One of the interesting features of RGM sternal wound infection is the delayed onset, as in our case. Although they are categorized as "rapidly growing" mycobacterium, the growth is slow compared to typical sternal infection organisms, such as Staphylococcus or gram negative bacilli. Chow reported a case whose first symptom started 11 months after the surgery. ${ }^{33}$ The average time from the surgery based on the available data was $49 \pm 58$ days. Whereas, typical bacterial sternal mediastinitis is reported to occur between 4 and 30 days, mostly within the first 2 weeks. ${ }^{34}$ The patients with RGM sternal infection do not appear to be septic in most cases. ${ }^{29}$ High fever with elevated WBC is rare in RGM sternal infection, in contrast to typical bacterial mediastinitis which the patients frequently present with fever, elevated WBC count, and a septic picture. ${ }^{35,36}$ Procalcitonin, a biomarker that increases in bacterial infection ${ }^{37}$, was only slightly elevated in our case. Sternal drainage is the most common presentation of RGM sternal infection, and in most cases, the drainage was odorless and 
watery rather than purulent. ${ }^{27}$ Presence of satellite abscesses are also characteristic. ${ }^{2}$ The initial aerobic and anaerobic cultures are usually negative, or it may grow normal flora of the skin, such as staphylococcus epidermidis or corynebacterium species. RGM grows on blood or MacConckey's agar but may take up to 7 days to culture. ${ }^{2}$ The delay of the isolation may cause delay in treatment, since the drug sensitivity is different from typical pathogen of sternal wound infection. $^{7}$

Antibiotics therapy: $\quad$ RGM is usually resistant to the first-line antituberculous drugs such as isoniazid, rifampin, and pyrazinamide..$^{5,38}$ In the reported outbreaks, antibiotics were selected based on sensitivity tests. $^{27,30}$ Hoffmann reported the use of kanamycin for 7-10 days, followed by erythromycin and rifampin. Kuritsky reported the use of amikacin and cefoxitin. Yew reported the efficacy of oral single daily dose oxacillin therapy. ${ }^{28}$ Clarithromycin is currently the drug of choice for M. chelonae and M. abscessus, because of the excellent tissue penetration, susceptibility and few side effects. ${ }^{35}$ Combination therapy is recommended to minimize the development of drug resistance..$^{35,39}$ Recently, linezolid, tigecycline, telithromycin, gatifloxacin are reported to be effective against RGM..$^{8,40}$ Approximately $50 \%$ of $M$. abscessus, $96 \%$ of $M$. fortuitum are susceptible to linezolid. ${ }^{8}$ At least 4 to 6 months of antibiotic treatment based on susceptibility test is recommended. ${ }^{8}$ In our case, clarithromycin was continued for 6 months.

For sternal infection caused by $M$. chelonae, one of the injectable agents such as imipenem, tobramycin was recommended in combination with clarithromycin for at least the first

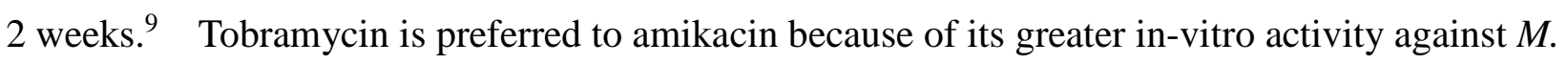
chelonae. $^{9}$ Oral agents such as minocycline and doxycycline are effective against only $20 \%$ of M. chelonae. $^{9}$ Cefoxitin which is used for M. abscessus is uniformly resistant for M. chelonae. $^{8}$

For sternal infections caused by $M$. abscessus, amikacin plus cefoxitin or imipenem is used for the first 2 to 6 weeks in combination with clarithromycin, until clinical improvement is 
evident. $^{8,9}$ M. abscessus is usually resistant against tobramycin. ${ }^{4}$ For the majority of $M$. abscessus and $M$. chelonae isolates, imipenem is the preferred carbapenem over meropenem and ertapenem. $^{8}$

Antibiotic therapy against M. fortuitum is much easier than M. abscessus or M. chelonae, since M. fortuitum is less drug resistant. Amikacin, cefoxitin, imipenem, sulfamethoxazole, and fluoroquinolones are recommended. ${ }^{9}$ Amikacin combined with beta-lactam (cefoxitin or imipenem) or a quinolone is used for initial therapy against serious infection. Yew reported the use of ofloxacin as a monotherapy ${ }^{41}$, but the development of mutational resistance resulted in treatment failure and relapse. ${ }^{9} \quad$ Therefore, if a quinolone is used, an additional antimicrobial agent should be used. $\quad 80 \%$ of $M$. fortuitum are susceptible to clarithromycin, but recent studies have shown that all isolates of $M$. fortuitum contain an erythromycin methylase gene erm, which may induce macrolide resistance. ${ }^{8}$

Surgical treatment: $\quad$ Surgical debridement in conjunction with appropriate antibiotic therapy is mandatory for complete recovery. Among the 70 reported cases, almost all cases underwent extensive drainage and debridement. All wires should be removed. If the combination of surgical debridement and appropriate antibiotics fails to eliminate the infection, more aggressive approach such as sternectomy combined with a pectoralis flap or omental flap will be required.

Outcomes: $\quad$ The outcome of the RGM sternal infection is not benign: 14 out of 49 cases died giving the overall mortality rate of $29 \%$, although 21 cases did not report the outcome. Of the 14 deaths, 6 cases $(75 \%, 6 / 8)$ had valve replacement surgery, 5 cases $(19 \%, 5 / 26)$ had CABG, $\mathrm{p}=0.003$. The common cause of mortality was prolonged sepsis, prosthetic valve endocarditis, and stroke. Robicsek reported that fatal hemorrhage from the aortotomy suture line and cannulation site, sepsis, prosthetic valve endocarditis resulting in stroke were the cause of 4 deaths in an outbreak in North Carolina. ${ }^{29}$ Narasimhan reported a case that developed 
mediastinitis 5 weeks after aortic valve replacement. In that report, mediastinitis caused sepsis, and subsequently infected the prosthetic valve. Emboli from the vegetation resulted in stroke and death. ${ }^{7}$ Chow reported a case of M. fortuitum superficial sternal wound infection that occurred 2 months after aortic and mitral valve replacement. The sternal wound was healed completely after 4 weeks of ofloxacin treatment; however, the patient was readmitted for RGM-aortic root abscess 11 months later from the initial procedure and resulted in mortality. ${ }^{33}$ In valve replacement surgery, prosthetic valves may be a nidus of RGM infection and would result in prolonged sepsis and endocarditis. The additional suture lines would be susceptible to mediastinal infection, which will eventually lead to uncontrollable bleeding, causing a high mortality rate in valve replacement surgery, compared to $\mathrm{CABG}^{27}$ If infection of RGM occurred after valve surgery and if the valve was infected, valve replacement with homograft should be considered.

Conclusion: It is possible that many reported cases of culture negative sternal wound infection may be due to mycobacterial infections, especially if the patient had a delayed onset and failed to response to standard antibiotic therapy. The diagnosis may be difficult, because the toxic signs are often subtle and it will take longer to isolate compared to typical bacteria. Delay of specific treatment may result in dismal outcomes. Early recognition, the use of appropriate antibiotics based on susceptibility tests and aggressive surgical debridement is required for full recovery. 


\section{Legends of figures}

Figure 1: CT scan showed substernal fluid collection with sternal dehiscence.

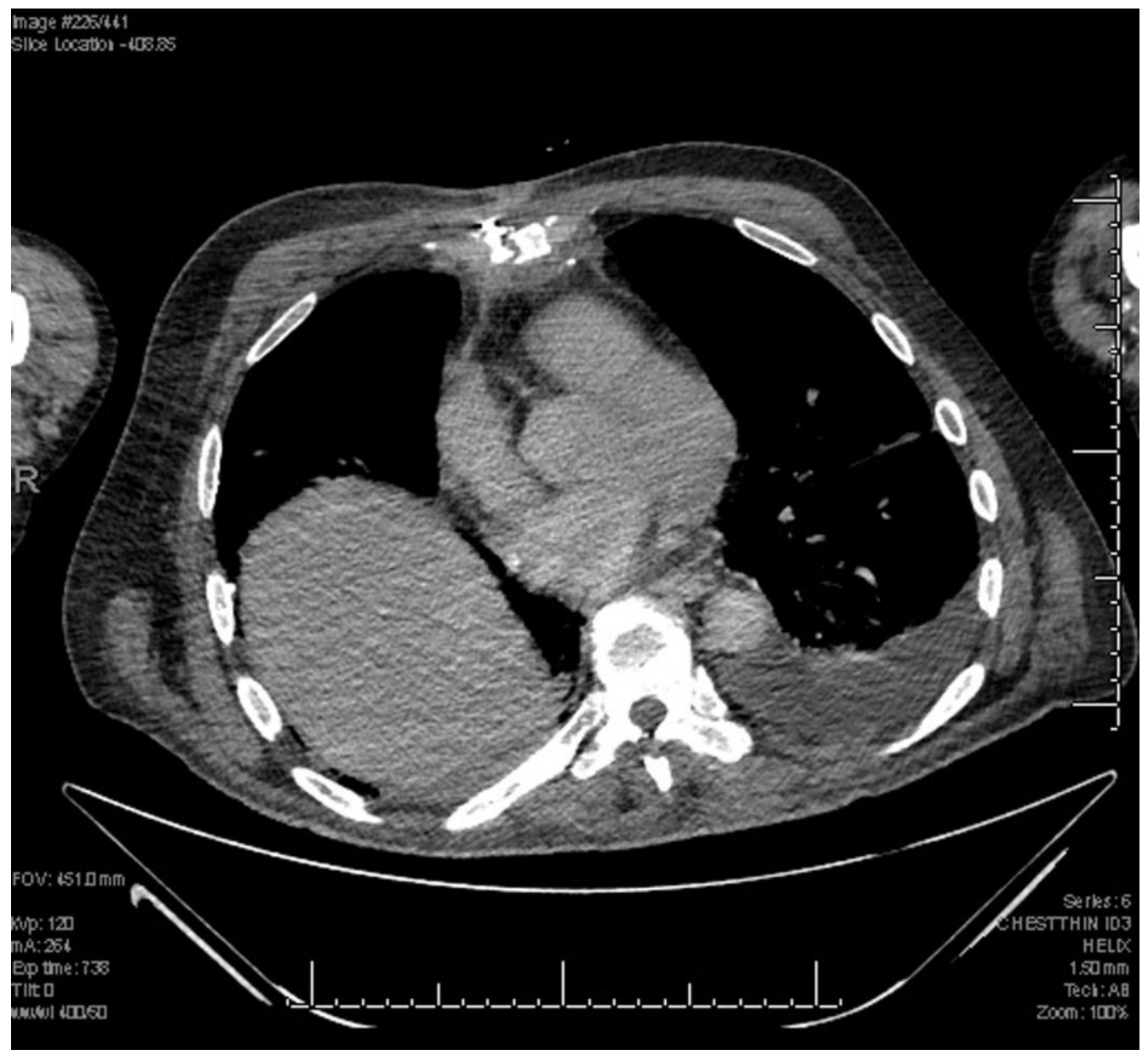


Table 1: Characteristics of the sternal infection caused by rapidly growing non-tuberculosis mycobacteria.

\begin{tabular}{|c|c|c|c|c|c|c|c|c|c|c|c|}
\hline Reference & Year & $\begin{array}{l}\text { No. of } \\
\text { cases } \\
(\text { sex })\end{array}$ & $\begin{array}{c}\text { Age } \\
\text { range } \\
\text { (median) }\end{array}$ & Place & Organism & $\begin{array}{c}\text { Duration } \\
\text { after } \\
\text { surgery } \\
\text { (median) }\end{array}$ & Fever & $\begin{array}{l}\text { Quality of } \\
\text { drainage }\end{array}$ & $\begin{array}{c}\text { WBC } \\
\text { (median) }\end{array}$ & $\begin{array}{l}\text { Long-term } \\
\text { antibiotics }\end{array}$ & Outcome \\
\hline Robicsek & 1976 & $\begin{array}{c}19 \\
(15 \text { male } \\
\text { and } \\
4 \text { female })\end{array}$ & $\begin{array}{l}42-66 \\
(57)\end{array}$ & $\begin{array}{l}\text { North } \\
\text { Carolina, } \\
\text { USA }\end{array}$ & $\begin{array}{c}\text { M. chelonei } \\
\text { subspecies } \\
\text { abscessus }\end{array}$ & $\begin{array}{c}\text { 6-40 } \\
\text { (14) days }\end{array}$ & low grade & $\begin{array}{l}\text { no odor, } \\
\text { more } \\
\text { watery } \\
\text { than } \\
\text { purulent }\end{array}$ & $\begin{array}{l}6.9-29.6 \\
(10.3)\end{array}$ & $\begin{array}{l}\text { erythromycin and } \\
\text { rifampin }\end{array}$ & 5 deaths \\
\hline Hoffman & 1976 & $\begin{array}{c}5 \\
(3 \text { male } \\
\text { and } 2 \\
\text { female })\end{array}$ & $\begin{array}{l}30-70 \\
(54.5)\end{array}$ & $\begin{array}{l}\text { Colorado, } \\
\text { USA }\end{array}$ & M. fortuitum & $\begin{array}{c}6-44 \\
\text { (25) days }\end{array}$ & NA & $\begin{array}{l}\text { thick, } \\
\text { whitish, } \\
\text { cheesy, } \\
\text { brown, or } \\
\text { purulent }\end{array}$ & $\begin{array}{l}7.0-18.5 \\
(9.2)\end{array}$ & $\begin{array}{l}\text { rifampin, } \\
\text { ethambutol, and } \\
\text { isoniazid (4) } \\
\text { ethionamide } \\
\text { ethambutol, and } \\
\text { isoniazid (1) }\end{array}$ & all healed \\
\hline Jauregui & 1977 & $\begin{array}{c}1 \\
\text { (male) }\end{array}$ & 55 & $\begin{array}{l}\text { Michigan, } \\
\text { USA }\end{array}$ & $\begin{array}{c}\text { M. chelonei } \\
\text { subspecies } \\
\text { abscessus }\end{array}$ & 61 days & $38^{\circ} \mathrm{C}$ & $\begin{array}{l}\text { yellowish, } \\
\text { white }\end{array}$ & 9.4 & $\begin{array}{l}\text { erythromycin and } \\
\text { vancomycin }\end{array}$ & $\begin{array}{l}\text { death } \\
\text { (bleeding } \\
\text { from } \\
\text { anastomo } \\
\text { sis) }\end{array}$ \\
\hline Szabo & 1977 & $\begin{array}{c}6 \\
(\operatorname{sex} \\
\text { unknown) }\end{array}$ & NA & Hungary & $\begin{array}{c}\text { M. chelonei } \\
\text { subspecies } \\
\text { abscessus }\end{array}$ & $\begin{array}{l}11-45 \\
\text { days }\end{array}$ & $\begin{array}{c}\text { fever (5) } \\
\text { no fever (1) }\end{array}$ & $\begin{array}{l}\text { serous, } \\
\text { containing } \\
\text { yellowish } \\
\text { fragment, } \\
\text { odorless }\end{array}$ & normal & NA & 3 deaths \\
\hline Narasimhan & 1978 & $\begin{array}{c}1 \\
\text { (male) }\end{array}$ & 57 & $\begin{array}{l}\text { Canada } \\
\text { (Ontario) }\end{array}$ & M. fortuitum & 5 weeks & $38.5^{\circ} \mathrm{C}$ & NA & 4.8 & $\begin{array}{l}\text { ethinamide, } \\
\text { isoniazid, and } \\
\text { rifampin }\end{array}$ & 1 death \\
\hline $\begin{array}{l}\text { Preheim } \\
\text { (reference } \\
\text { Brown-Ell } \\
\text { iott 2002) }\end{array}$ & 1981 & $\begin{array}{c}5 \\
(\operatorname{sex} \\
\text { unknown })\end{array}$ & NA & $\begin{array}{l}\text { Nebraska, } \\
\text { USA }\end{array}$ & M. fortuitum & NA & NA & NA & NA & NA & 1 death \\
\hline
\end{tabular}




\begin{tabular}{|c|c|c|c|c|c|c|c|c|c|c|c|}
\hline Kuritsky & 1981 & $\begin{array}{c}4 \\
\text { (all male) }\end{array}$ & $\begin{array}{l}49-76 \\
(62.5)\end{array}$ & $\begin{array}{l}\text { Texas, } \\
\text { USA }\end{array}$ & $\begin{array}{l}\text { M. chelonei } \\
\text { subspecies } \\
\text { abscessus, } \\
\text { M. fortuitum } \\
\text { biovariant } \\
\text { fortuitum }\end{array}$ & $\begin{array}{c}21-92 \\
\text { (26) days }\end{array}$ & $\begin{array}{r}\text { fever }(2), \\
\text { no fever }(2)\end{array}$ & NA & NA & $\begin{array}{c}\text { amikacin and } \\
\text { cefoxitin (2) } \\
\text { amikacin, cefoxitin } \\
\text { and doxycycline (1) }\end{array}$ & $\begin{array}{l}1 \text { death, } \\
3 \text { healed }\end{array}$ \\
\hline Sethi & 1982 & 1 (male) & 61 & $\begin{array}{l}\text { North } \\
\text { Carolina, } \\
\text { USA }\end{array}$ & M. fortuitum & 30 days & $37.8^{\circ} \mathrm{C}$ & $\begin{array}{l}\text { serous, } \\
\text { odorless }\end{array}$ & 4.4 & $\begin{array}{c}\text { doxycycline, } \\
\text { sulphamethoxazole, } \\
\text { and ethionamide }\end{array}$ & 1 healed \\
\hline Kuhn & 1983 & $\begin{array}{c}1 \\
\text { (male) }\end{array}$ & 56 & Indiana & M. fortuitum & 28 days & low grade & $\begin{array}{l}\text { brown } \\
\text { purulent }\end{array}$ & & $\begin{array}{c}\text { ciprofloxacin, } \\
\text { erythromycin, and } \\
\text { amikacin }\end{array}$ & 1 death \\
\hline Yew & $\begin{array}{l}1987 \\
- \\
1989\end{array}$ & $\begin{array}{c}21 \\
(13 \text { male } \\
\text { and } 8 \\
\text { female })\end{array}$ & $\begin{array}{c}28-70 \\
(58)\end{array}$ & Hong Kong & $\begin{array}{c}\text { M. fortuitum } \\
\text { biovariant } \\
\text { fortuitum (7) } \\
\text { M. fortuitum } \\
\text { biovariant } \\
\text { peregrinum (12) } \\
\text { M. fortuitum third } \\
\text { biovariant complex } \\
\text { (2) }\end{array}$ & $\begin{array}{c}0-2 \\
\text { months }\end{array}$ & NA & NA & NA & NA & NA \\
\hline Chow & 1988 & $\begin{array}{c}1 \\
\text { (female) }\end{array}$ & 45 & Hong Kong & M. fortuitum & 11 months & NA & NA & NA & oxacillin & 1 death \\
\hline Samuels & 1996 & $\begin{array}{c}1 \\
\text { (female) }\end{array}$ & 49 & PA, USA & M. fortuitum & 35 days & low grade & watery & NA & $\begin{array}{c}\text { ciprofloxacin, } \\
\text { sulfamethoxazole, } \\
\text { and clarithromycin }\end{array}$ & 1 healed \\
\hline Syed & 1997 & $\begin{array}{c}1 \\
\text { (male) }\end{array}$ & 6 & $\begin{array}{c}\text { Saudi } \\
\text { Arabia }\end{array}$ & M. fortuitum & 19 days & $38.5^{\circ} \mathrm{C}$ & $\begin{array}{l}\text { yellowish, } \\
\text { odorless, } \\
\text { thick pus }\end{array}$ & & $\begin{array}{c}\text { amikacin, } \\
\text { sulfamethoxazole } \\
\text { and trimethoprim }\end{array}$ & 1 healed \\
\hline Idigoras & 2003 & $\begin{array}{c}1 \\
\text { (male) }\end{array}$ & 78 & Spain & M. porcinum & 6 months & NA & pus & NA & ciprofloxacin & 1 healed \\
\hline
\end{tabular}




\begin{tabular}{|c|c|c|c|c|c|c|c|c|c|c|c|}
\hline Sarma & 2010 & $\begin{array}{c}1 \\
\text { (male) }\end{array}$ & 75 & India & M. abscessus & 1 month & No & $\begin{array}{l}\text { serosangui } \\
\text { nous }\end{array}$ & 10.4 & $\begin{array}{l}\text { azithromycin, } \\
\text { amikacin, and } \\
\text { ciprofloxacin }\end{array}$ & 1 healed \\
\hline Unai & 2013 & $\begin{array}{c}1 \\
\text { (male) }\end{array}$ & 60 & PA USA & M. chelonae & 3 months & No & $\begin{array}{l}\text { serosangui } \\
\text { nous }\end{array}$ & 7.6 & $\begin{array}{l}\text { tigecycline, and } \\
\text { clarithromycin }\end{array}$ & 1 healed \\
\hline
\end{tabular}

NA: not available; WBC: white blood cell count (B/L). 


\section{Reference}

1. Sjogren J, Malmsjo M, Gustafsson R, Ingemansson R. Poststernotomy mediastinitis: a review of conventional surgical treatments, vacuum-assisted closure therapy and presentation of the Lund University Hospital mediastinitis algorithm. Eur J Cardiothorac Surg 2006;30:898-905.

2. Syed AU, Hussain R, Bhat AN, al Rasheed M, al Qethami H, al Faraidi Y, al Fagih MR. Mediastinitis due to Mycobacterium fortuitum infection following Fontan operation in a child. Scand Cardiovasc J 1997;31:311-3.

3. Lador A, Nasir H, Mansur N, Sharoni E, Biderman P, Leibovici L, Paul M. Antibiotic prophylaxis in cardiac surgery: systematic review and meta-analysis. J Antimicrob Chemother 2012;67:541-50.

4. Gayathri R, Therese KL, Deepa P, Mangai S, Madhavan HN. Antibiotic susceptibility pattern of rapidly growing mycobacteria. J Postgrad Med 2010;56:76-8.

5. Esteban J, Ortiz-Perez A. Current treatment of atypical mycobacteriosis. Expert Opin Pharmacother 2009;10:2787-99.

6. Nagao M, Sonobe M, Bando T, Saito T, Shirano M, Matsushima A, Fujihara N, Takakura S, Iinuma Y, Ichiyama S. Surgical site infection due to Mycobacterium peregrinum: a case report and literature review. Int J Infect Dis 2009;13:209-11.

7. Narasimhan SL, Austin TW. Prosthetic valve endocarditis due to Mycobacterium fortuitum. Can Med Assoc J 1978;119:154-5.

8. Griffith DE, Aksamit T, Brown-Elliott BA, Catanzaro A, Daley C, Gordin F, Holland SM, Horsburgh R, Huitt G, Iademarco MF, Iseman M, Olivier K, Ruoss S, von Reyn CF, Wallace RJ, Jr., Winthrop K. An official ATS/IDSA statement: diagnosis, treatment, and prevention of nontuberculous mycobacterial diseases. Am J Respir Crit Care Med 
2007; 175:367-416.

9. Brown-Elliott BA, Wallace RJ, Jr. Clinical and taxonomic status of pathogenic nonpigmented or late-pigmenting rapidly growing mycobacteria. Clin Microbiol Rev 2002;15:716-46.

10. Center for Disease Control: Follow-up on mycobacterial contamination of porcine heart valve prostheses - United States. Morbidity Mortality Weekly Rep 1978;27:92.

11. Grange JM. Mycobacterial infections following heart valve replacement. J Heart Valve Dis $1992 ; 1: 102-9$.

12. Rumisek JD, Albus RA, Clarke JS. Late Mycobacterium chelonei bioprosthetic valve endocarditis: activation of implanted contaminant? Ann Thorac Surg 1985;39:277-9.

13. Laskowski LF, Marr JJ, Spernoga JF, Frank NJ, Barner HB, Kaiser G, Tyras DH. Fastidious mycobacteria grown from porcine prosthetic-heart-valve cultures. N Engl J Med 1977;297:101-2.

14. Wallace RJ, Jr., Brown BA, Griffith DE. Nosocomial outbreaks/pseudo-outbreaks caused by nontuberculous mycobacteria. Annu Rev Microbiol 1998;52:453-90.

15. Tsai WC, Hsieh HC, Su HM, Lu PL, Lin TH, Sheu SH, Lai WT. Mycobacterium abscessus endocarditis: a case report and literature review. Kaohsiung J Med Sci 2008;24:481-6.

16. Al-Benwan K, Ahmad S, Mokaddas E, Johny M, Kapoor MM. Diagnosis of endocarditis caused by Mycobacterium abscessus. Ann Saudi Med 2010;30:408-11.

17. Williamson JC, Miano TA, Morgan MR, Palavecino EL. Fatal Mycobacterium abscessus endocarditis misidentified as Corynebacterium spp. Scand J Infect Dis 2010;42:222-4.

18. Brown BA, Springer B, Steingrube VA, Wilson RW, Pfyffer GE, Garcia MJ, Menendez MC, Rodriguez-Salgado B, Jost KC, Jr., Chiu SH, Onyi GO, Bottger EC, Wallace RJ, Jr. 
Mycobacterium wolinskyi sp. nov. and Mycobacterium goodii sp. nov., two new rapidly growing species related to Mycobacterium smegmatis and associated with human wound infections: a cooperative study from the International Working Group on Mycobacterial Taxonomy. Int J Syst Bacteriol 1999;49 Pt 4:1493-511.

19. Bonicke R. The occurrence of atypical mycobacteria in the environment of man and animal. Bull Int Union Tuberc Lung Dis 1966;37:361-8.

20. Pattyn SR, Magnusson M, Stanford JL, Grange JM. A study of Mycobacterium fortuitum (ranae). J Med Microbiol 1974;7:67-76.

21. Kusunoki S, Ezaki T. Proposal of Mycobacterium peregrinum sp. nov., nom. rev., and elevation of Mycobacterium chelonae subsp. abscessus (Kubica et al.) to species status: Mycobacterium abscessus comb. nov. Int J Syst Bacteriol 1992;42:240-5.

22. Lévy-Frébault V, Grimont F, Grimont PA, David HL. Deoxyribonucleic Acid Relatedness Study of the Mycobacterium fortuitum-Mycobacterium chelonae Complex. Int J Syst Bacteriol 1986;36:458-60.

23. Silcox VA, Good RC, Floyd MM. Identification of clinically significant Mycobacterium fortuitum complex isolates. J Clin Microbiol 1981;14:686-91.

24. Vilaplana C, Cardona PJ. Tuberculin immunotherapy: its history and lessons to be learned. Microbes Infect 2010;12:99-105.

25. Hill LR, Skerman VBD, Sneath PHA. Corrigenda to the Approved Lists of Bacterial Names edited for the International Committee on Systematic Bacteriology. Int J Syst Bacteriol 1984;34:508-11.

26. Kubica GP, Baess I, Gordon RE, Jenkins PA, Kwapinski JB, McDurmont C, Pattyn SR, Saito H, Silcox V, Stanford JL, Takeya K, Tsukamura M. A co-operative numerical analysis of rapidly growing mycobacteria. J Gen Microbiol 1972;73:55-70. 
27. Hoffman PC, Fraser DW, Robicsek F, O'Bar PR, Mauney CU. Two outbreaks of sternal wound infection due to organisms of the Mycobacterium fortuitum complex. J Infect Dis $1981 ; 143: 533-42$.

28. Yew WW, Kwan SY, Ma WK, Khin MA, Mok CK. Single daily-dose ofloxacin monotherapy for Mycobacterium fortuitum sternotomy infection. Chest 1989;96:1150-2.

29. Robicsek F, Daugherty HK, Cook JW, Selle JG, Masters TN, O'Bar PR, Fernandez CR, Mauney CU, Calhoun DM. Mycobacterium fortuitum epidemics after open-heart surgery. J Thorac Cardiovasc Surg 1978;75:91-6.

30. Kuritsky JN, Bullen MG, Broome CV, Silcox VA, Good RC, Wallace RJ, Jr. Sternal wound infections and endocarditis due to organisms of the Mycobacterium fortuitum complex. Ann Intern Med 1983;98:938-9.

31. Wallace RJ, Jr., Musser JM, Hull SI, Silcox VA, Steele LC, Forrester GD, Labidi A, Selander RK. Diversity and sources of rapidly growing mycobacteria associated with infections following cardiac surgery. J Infect Dis 1989;159:708-16.

32. Sethi GK, Simons WJ, Scott SM. Mycobacterium fortuitum infections of the mediastinum. J Cardiovasc Surg (Torino) 1985;26:307-9.

33. Chow WH, Leung WH, Tai YT, Lee WT, Cheung KL. Echocardiographic diagnosis of an aortic root abscess after Mycobacterium fortuitum prosthetic valve endocarditis. Clin Cardiol 1991;14:273-5.

34. Sarr MG, Gott VL, Townsend TR. Mediastinal Infection after Cardiac Surgery. Ann Thorac Surg 1984;38:415-23.

35. Samuels LE, Sharma S, Morris RJ, Solomon MP, Granick MS, Wood CA, Brockman SK. Mycobacterium fortuitum infection of the sternum. Review of the literature and case illustration. Arch Surg 1996;131:1344-6. 
36. Vaska PL. Sternal wound infections. AACN Clin Issues Crit Care Nurs 1993;4:475-83.

37. Riedel S. Procalcitonin and the role of biomarkers in the diagnosis and management of sepsis. Diagn Microbiol Infect Dis 2012;73:221-7.

38. American Thoracic Society: Diagnosis and treatment of disease caused by nontuberculous mycobacteria. This official statement of the American Thoracic Society was approved by the Board of Directors, March 1997. Medical Section of the American Lung Association. Am J Respir Crit Care Med 1997;156:S1-25.

39. Mushatt DM, Witzig RS. Successful treatment of Mycobacterium abscessus infections with multidrug regimens containing clarithromycin. Clin Infect Dis 1995;20:1441-2.

40. Fernandez-Roblas R, Martin-de-Hijas NZ, Fernandez-Martinez AI, Garcia-Almeida D, Gadea I, Esteban J. In vitro activities of tigecycline and 10 other antimicrobials against nonpigmented rapidly growing mycobacteria. Antimicrob Agents Chemother 2008;52:4184-6.

41. Yew WW, Kwan SY, Ma WK, Lui KS, Suen HC. Ofloxacin therapy of Mycobacterium fortuitum infection: further experience. J Antimicrob Chemother 1990;25:880-1. 